Interfaces

\title{
Création/Destruction
}

\section{Maxime Leroy, A Study of Authorial Illustration: The Magic Window}

\section{Evanghelia Stead}

\section{(2) OpenEdition}

1 Journals

Electronic version

URL: http://journals.openedition.org/interfaces/824

DOI: 10.4000/interfaces.824

ISSN: 2647-6754

Publisher:

Université de Bourgogne, Université de Paris, College of the Holy Cross

\section{Printed version}

Date of publication: 15 July 2020

Number of pages: 159-161

ISSN: $1164-6225$

\section{Electronic reference}

Evanghelia Stead, « Maxime Leroy, A Study of Authorial Illustration: The Magic Window », Interfaces

[Online], 43 | 2020, Online since 15 July 2020, connection on 04 January 2021. URL : http:// journals.openedition.org/interfaces/824; DOI : https://doi.org/10.4000/interfaces.824

Les contenus de la revue Interfaces sont mis à disposition selon les termes de la Licence Creative Commons Attribution 4.0 International. 


\title{
Maxime Leroy, A Study of Authorial Illustration: The Magic Window, Newcastle upon Tyne, Cambridge Scholars Publishing, 2019, viii, 101 pp.
}

\author{
Evanghelia Stead \\ Université de Versailles Saint-Quentin (Paris-Saclay) - Institut Universitaire de France
}

Maxime Leroy's short study on writers' own illustration has two parts and a conclusion. The twofold structure opens with a long dialogue, "A Conversation on Authorial Illustration" (p. 5-44), presents twelve case studies (p. 45-90), and briefly concludes with a few principles. The device of the inaugural interview is an appealing entry into the subject matter at hand. It starts with simple questions-cumdefinitions and moves to more complicated ones, citing various examples and critical views, clarifying terminology. Its aim is to compensate for a lack of theory and theorized practice on authorial illustration, mainly in its symbolic and aesthetic aspects, while considering styles, publishing, marketing and authors' control over books. The stress is largely on narrative works and Victorian illustration (with three $20^{\text {th }}$-century additions), while occasional Japanese quotes or random European (mainly French) examples fail to underpin the author's European interests.

Senior lecturer in English studies at Université de Haute-Alsace, Maxime Leroy is well read in predominantly English-language criticism. His varied approach to illustration is one of the book's clearer advantages. Leroy considers it a deceptive screen (as in W. J. T. Mitchell, frequently quoted), an illumination (Thackeray), but also a device creating conflict and divergence with text. He ably criticizes the narrowness of illustration as a critical term and proposes a range of definitions, targeting both the power of the reader and complex results of hybrid and cross readings. In this sense, he might further stress imprecision, blurring, darkness and their enigmatic effects in illustration. The book offers up interesting and useful commentary of images from dreams, as in pages 3I-32 (that refer to the mammoth illustrating the cover). More extensive analysis along these lines would be welcome. Another advantage is Leroy's criticism of Gérard Genette's paratext, a notion unable to capture the multiple aspects of illustration and the manifold parts it plays in print. 
Leroy addresses relations between authorial illustration, narrative and peritextual elements, often investigating other texts by authors, or works of art and print. His study's strongest claim is a systemic approach (p. 29-32), bringing together elements that allow the reader to capture the wealth of potential in such works. Authorial illustration is promoted as a coalescent form aimed at liberty of construction and interpretation, whose purpose supports the reader in grasping authors' ambitions. Conventional separation of codes, even the intermedial approach, are pitted against coalescence, as Leroy highlights the contradiction between narrative voices or hybrid effects in triptychs. He diagrams his methodology (p. 3I) with any author's illustration sitting in the centre of seven circles: I) the relevant passage in text; 2) other parts of text; 3) other illustrations in the book; 4) authors' other illustrations of the passage; 5) other artists' illustrations of the page; 6) the reader's mental image; 7) any other image. The graph also hosts a circle open to additional analysis or authorial inventions that have not been broached. Similarly, the dialogue ends with "The conversation must continue" (p. 44). Such open-mindness is productive and welcome but it is debatable whether the invitation to consider "any other image" is truly useful. It opens investigation to perhaps too many options, a perspective that is hardly devoid of risk.

The difficulty of a universal approach to authorial illustration is exemplified in the array of case studies. These comprise famous authors (Thackeray, Carroll, Twain, Kipling, Stevenson), well known (Du Maurier, Jacques-Émile Blanche), and lesser-known ones (Samuel Lover, Cuthbert Bede, Robert Michael Ballantyne, Edith E. Somerville and Martin Ross, Jeanne Ramel-Cals, G. R. G. Worcester). They embrace various genres: novels, a comic strip, a reproduction manuscript, short magazine texts, travel writing, autobiography, a poem, and a short story. Narration, ideology, parody, irony, satire, concealed sexuality, and grief interplay with reality, fictionality or artistic references. Critical intention varies: some developments consider authorial illustration in relation to reception studies, readers' expectations, ideological, sexual or cultural constructions. Others show how illustration engages readers in the transformation process, with Didi-Hubermann's detail and pan as reference, or with text or paratext. The case studies are generally short, though brevity is not always of advantage. An illustration of Robert Michael Ballantyne's Erling the Bold builds heavily on extant criticism but opens up several channels to little effect. Jacques-Émile Blanche's Aymeris (1922) is curtly analysed, and the purpose of the few pages devoted to Jeanne Ramel-Cal's Vacances à Villefranche (1927) is vague. Inversely, the Saint Catherine motive in Thackeray's Vanity Fair is as illuminating as Leroy's welcome article on Echo in Du Maurier's Trilby published in Polysèmes (2018).

There are strange omissions to the final bibliography. Some references are given only in the text, others are absent, including the author's own. Some in-text references to web pages are unclear. A few oversights include Herbert Cahoon, "The Author as Illustrator" (in Book Illustration, Berlin, Gebr. 
Mann Verlag, I963), and the special issue of Revue de l'art (I979, $\mathrm{n}^{\circ} 44$ ) offering a wide approach of authorial illustration in dictionary form. Corrections might include the etymology of monster (from the Latin verbs monstrare or monere which do not mean "an abnormal shape"), Huysmans' first name (Joris-Karl, not inverted), as well as a few typos.

On the whole, Leroy's study contributes usefully to the complexity of illustration, particularly authorial. Lastly, it draws much needed attention to symbolism, heterogeneity, metaphysical preoccupations and the interaction of an array of varied elements in illustrated books. 